\title{
Imagining Oceania: Indigenous and \\ Foreign Representations of a \\ Sea of Islands
}

\section{Margaret Jolly}

\section{CARtographies}

In imagining any region of the world today we often start with cartography-with a map. ${ }^{1}$ Yet the maps we draw are never reflections of the world as it is, but always partial representations of it-representations powerfully shaped by who we are, where and when we are, and what motivates our interests in that place. ${ }^{2}$ Maps of Japan appropriate to tourist sojourning, to seismic charting, to military conquest, or to developmentalist economics would differ radically. ${ }^{3}$ In this article I look at several maps of the Pacific, generated in different places and times and for different purposes. But let me start with two maps that derive from the late eighteenth century.

The first is the map of Tupaia, a man from Ra'iatea, priest of the 'Oro religion, member of the arioi cult, and adviser to the chiefs of Tahiti. ${ }^{4}$ (See figure I). Tupaia joined the Endeavour when Captain Cook left Tahiti in the Society Islands in July I769. Cook thought him immensely intelligent and knowledgeable both about the geography of the islands and the varied customs of its peoples. Joseph Banks sought his assistance as an interpreter and desired to take him back to England as a "curiosity." Unlike Omai (see Hetherington 200I; Jolly nd b), Tupaia never made it to England; he died en route, in Batavia in December I770. But some of his extensive knowledge of his island world was passed on as a map. The original drawing was lost, but several copies were made, including the version published in Johann Reinhold Forster's magnum opus, Observations Made During a Voyage Round the World (Forster I778; 1996, 304-305). Forster and his son Georg were the naturalists on the second of Cook's voyages-voyages

The Contemporary Pacific, Volume 19, Number 2, 508-545

(C) 2007 by University of Hawai i Press 
that generated another cartography of the Pacific, as reflected in a map of the tracks of the sailing ships on Cook's three voyages. (See figure 2).

I juxtapose these two maps to ponder the relationship between indigenous and foreign representations of Oceania and to situate such representations in the changing histories of relations between Pacific peoples and strangers, between Islanders and those who are called (tongue-in-cheek, in an important volume [Borofsky 2000]), "Outlanders." Indigenous and foreign representations of the place and its peoples are now not so much separate visions as they are "double visions," in the sense of both stereoscopy and blurred edges. Foreign knowledges of the Pacific have both used and aspired to eclipse indigenous knowledges, as is obvious from the earliest forms of ethnology in the region. ${ }^{5}$ Indigenous visions have, since the late eighteenth century, been challenged and partially transformed through encounters with the imagined cartographies of travelers, missionaries, traders, planters, and other agents of colonialism, capitalism, and development. As Tongan scholar Epeli Hau'ofa has suggested (I994), outsiders' representations of the Pacific matter not just because of their geopolitical and discursive hegemony but because Islanders have, in part, come to see themselves through the Outlanders' lenses.

But how far and how do constructs of place and people that emanate from "beyond the horizon" displace local visions? Tupaia's map is a good example. Though he is the author, this map is not his indigenous view. We will never know the details of that view, but his vision was likely a rather differently "situated knowledge." ${ }^{6}$ I suspect it located the observer not soaring high above the islands, powerfully riding on the confident coordinates of longitude and latitude, plotting a changing global position relative to east and west, north and south, but rather lying low in a canoe, looking up at the heavens, scanning the horizon for signs of land, and navigating the powerful seas with the embodied visual, aural, olfactory, and kinesthetic knowledge passed down through generations of Pacific navigators. His knowledge would have been communicated to other Tahitians through genealogical stories and chants, through the materials of the canoe and the sails, and through the embodied practice of navigation (see Finney 1992; Finney and others I994; and the film Sacred Vessels [Diaz I997]). ${ }^{7}$ Such full-bodied knowledge is here etiolated and converted through the agency of a quill and a piece of parchment into a map. Moreover, the Tahitian names and dispositions of islands are not just written down and graphed as a map, but situated in and saturated by the discursive frame of "discovery" of Enlightenment voyaging. ${ }^{8}$ 


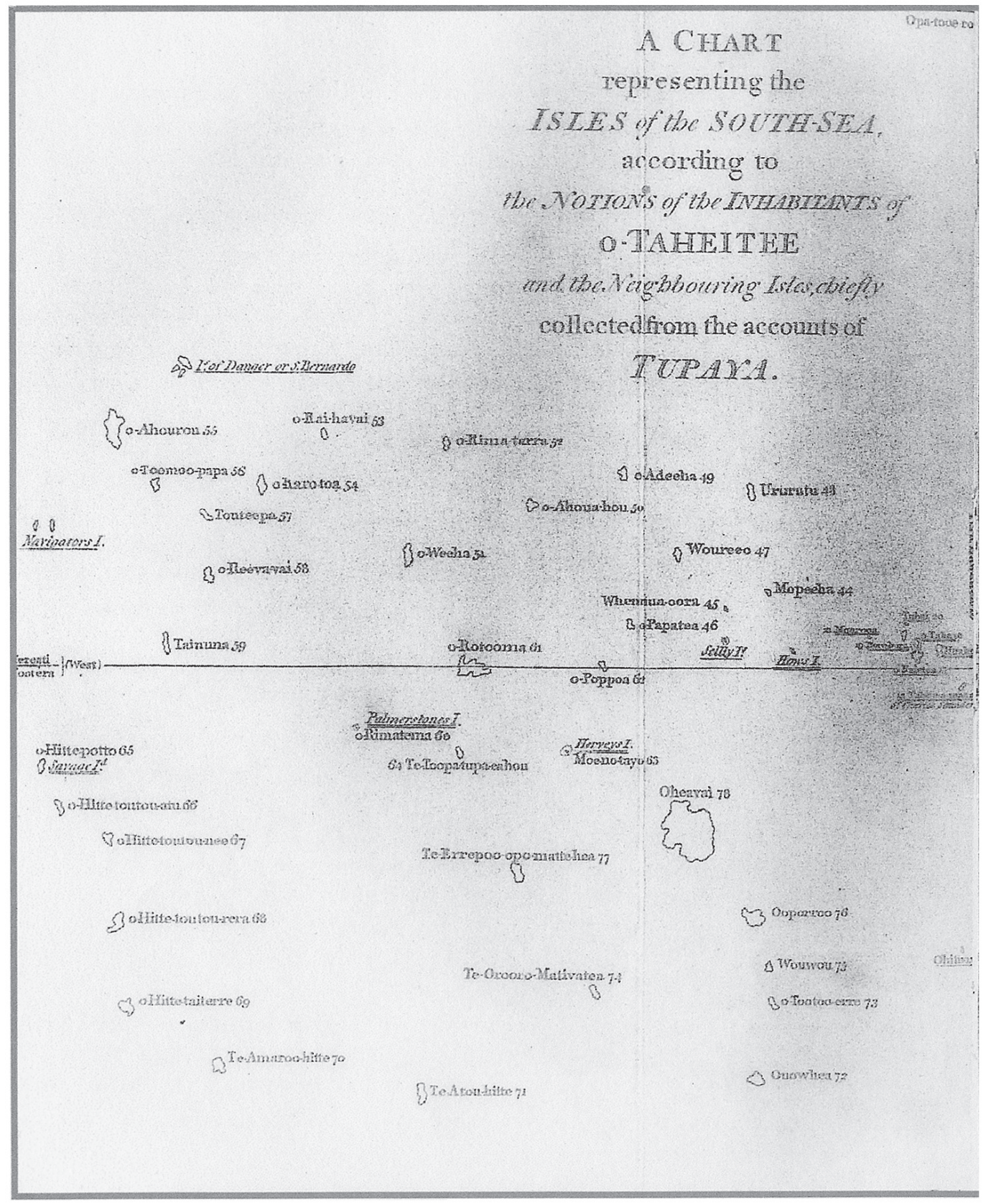

Figure I. “Tupaia’s Map,” reproduced from Forster 1996, 303-304; this version 


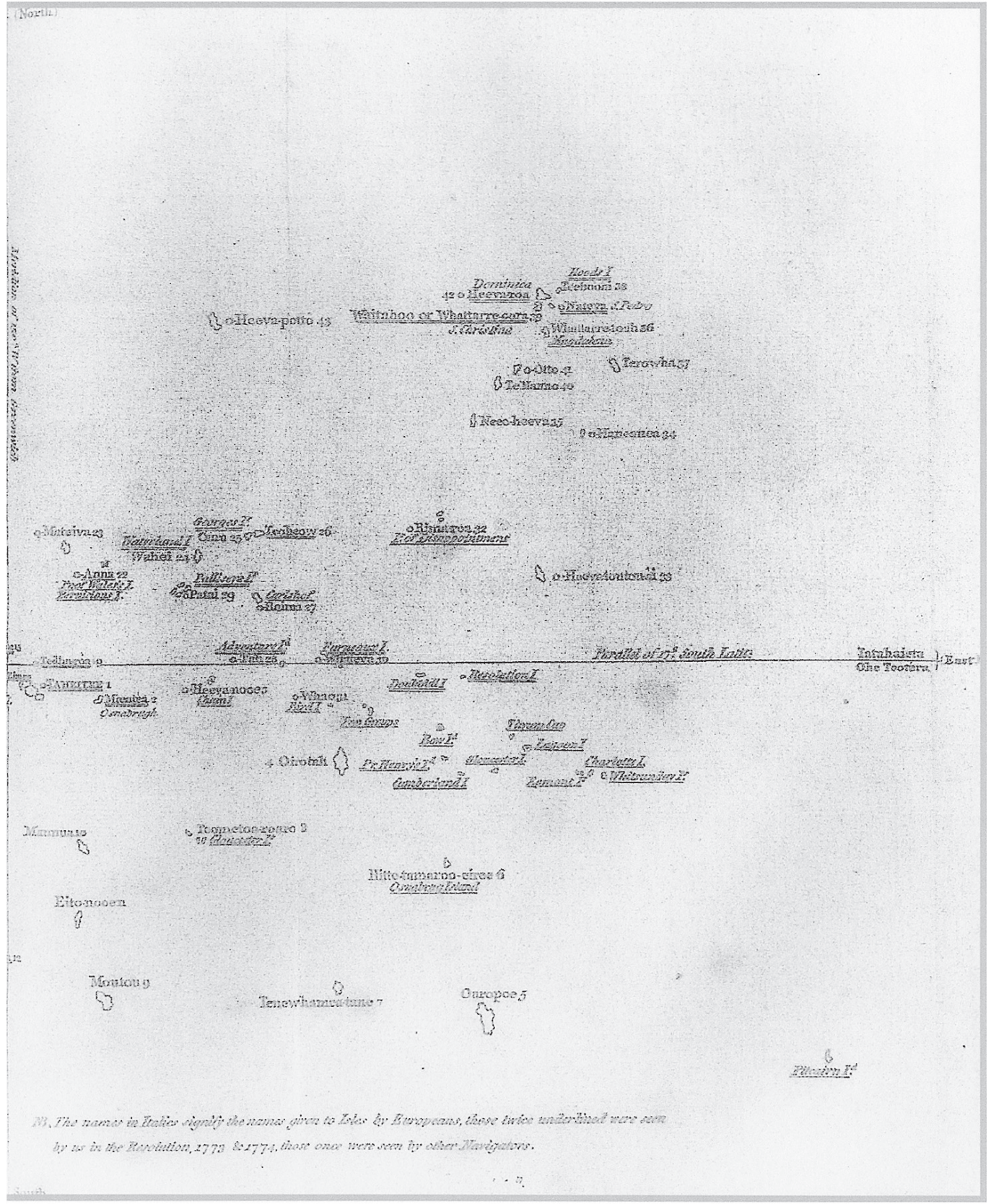

of the map was first published almost 230 years ago (Forster I 778 ). 


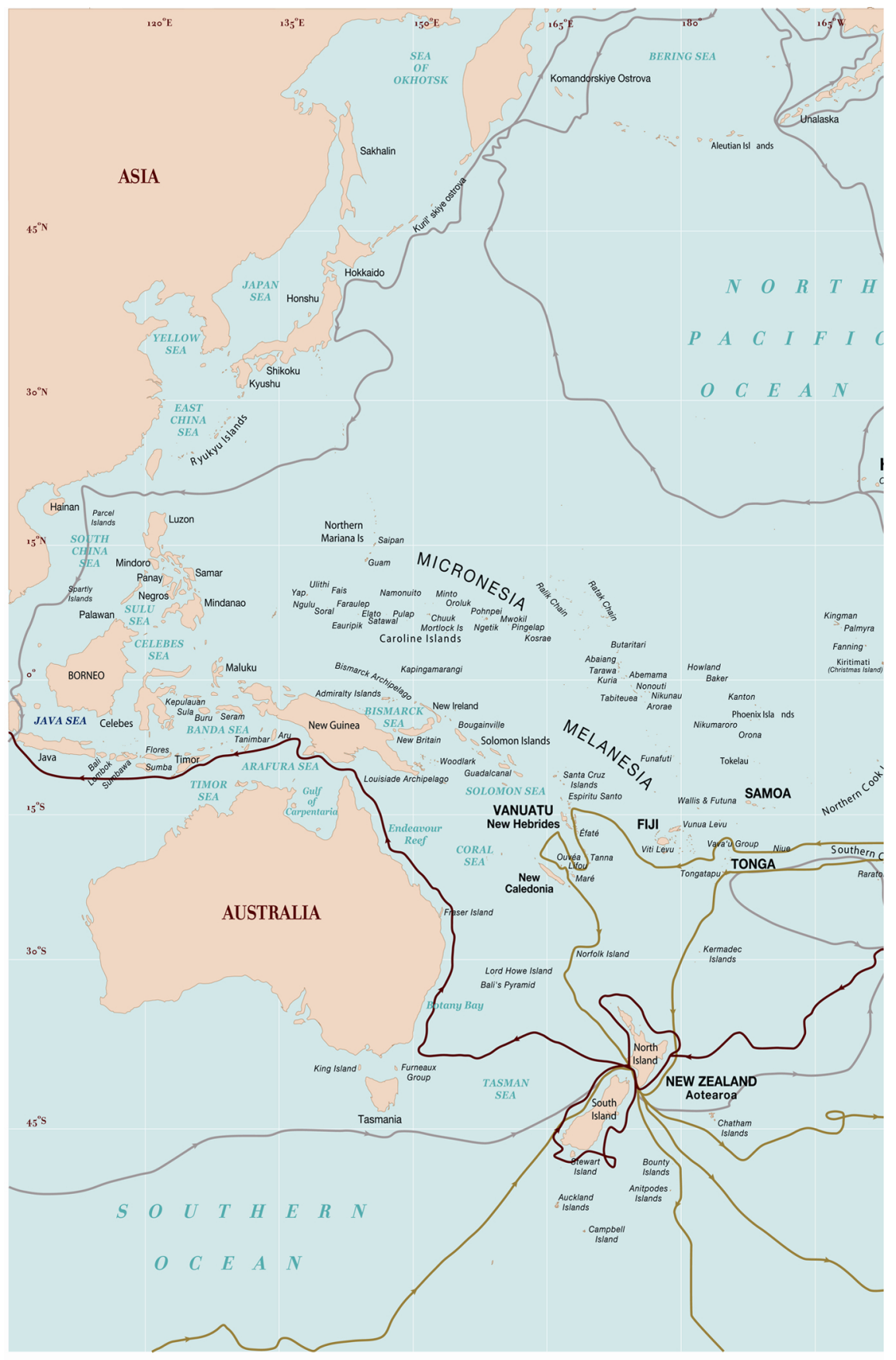

Figure 2. Reproduced with permission from Cook's Pacific Encounters exhibit catalog (National Museum of Australia 2006, r07). (C) National Museum of Australia 2006. 


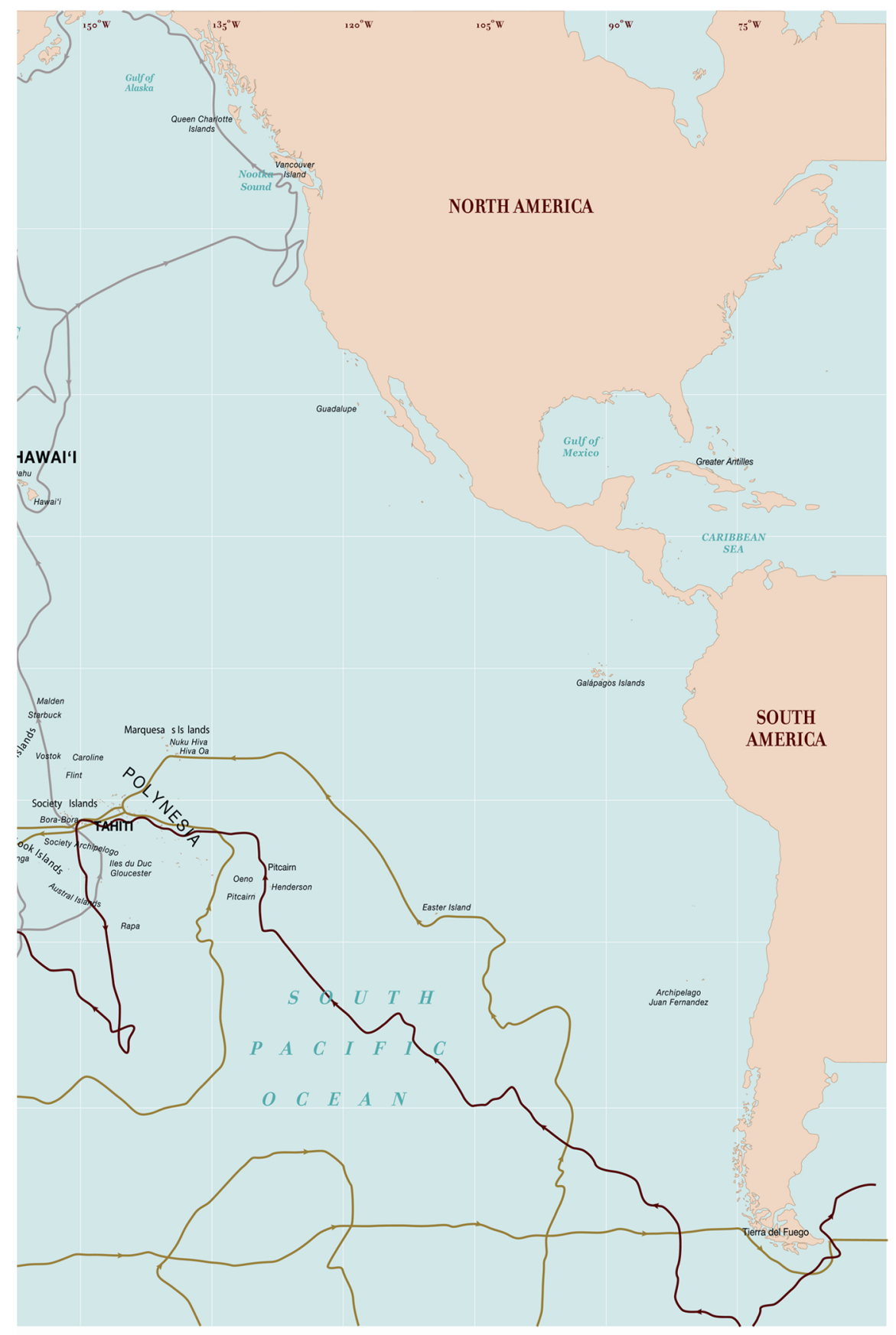

Pacific voyages of Captain James Cook

- First voyage $1768-1771$

Second voyage $1772-1775$ Third voyage 1776-1780 
But we might start the "history" of the Pacific, not in I768 (with Cook) or even in the sixteenth century with previous explorers from Holland or Spain, but with the movement of the first peoples into this ocean. The first movements, at about 40,000 BP, were made by the ancestors of those who live in the interior of Papua New Guinea and speak Papuan languages. A later wave of migrants who came from Asia, probably from around 5,000-6,000 BP, were the ancestors of those people who speak Austronesian languages and who today inhabit much of insular Southeast Asia and the Pacific. ${ }^{9}$ They moved through these islands and across the Pacific in several waves of migration. Their "voyages of discovery" were made many centuries before journeys by European explorers - Quirós, Bougainville, Cook, and many others-who are still too often proclaimed, in racist ignorance or hubris, the "discoverers" (see Jolly forthcoming, nd a).

The energy and acumen of these first "discoverers" is witnessed in the extraordinary history of the Austronesian-speaking peoples moving from their homelands in South China (or Taiwan, or both) across the vast liquid expanse of the Pacific Ocean. This extended process of long-distance navigation in oceangoing canoes without charts and compasses - navigating by the stars, sun, and moon, the swells of the ocean and its currents, the direction and the strength of the prevailing winds, the movement of birds, the subtle signs of land - spread settlers from the western islands of what is now Papua New Guinea, the Solomons, New Caledonia, Vanuatu, and Fiji, north to Palau, Guam, and the Marshalls, east to Sāmoa, Tonga, the Cook Islands, and Rapa Nui, south to Aotearoa/New Zealand, and north to Hawai' ${ }^{1} .{ }^{10}$ (See figure 3 ).

This ancient story of movement and settlement is narrated in different ways in hundreds of extant Austronesian languages, in a genre that Hawaiian scholar Lilikalā Kame'eleihiwa has called "genealogical history" ( I992, 23-24). This connects places and peoples through the spatiotemporal language of kinship; it plots origins and destinations, connections and disconnections in the relation of divine beings and past ancestors to living descendants. Hawaiian epic traditions start with the union of the half siblings Wākea (sky father) and Papa (earth mother). Their incestuous union generated not only a beautiful daughter but also the several islands of the Hawaiian chain. Genealogical histories are still told across much of the Pacific, although the variety and complexity of these genealogies and the variable relation to hierarchy can only be alluded to here. Many start with origin or "creation" moments, in a time when land and ocean were first formed, when male and female difference was first marked, when the 
world of light was separated from the world of darkness. So, for instance, Māori relate the canonical whakapapa (genealogy), telling of how the separation of the sky father, Ranginui, from the earth mother, Papatuanuku, distinguished the world of light from the world of darkness. Māori also tell of the arrival of a "great fleet" of several waka or canoes from the homeland of Hawaiki, and how with the dispersal of these several canoes of settlers across the north and south islands of Aotearoa/New Zealand, different iwi (people, bones) were attached to different places. Other genealogical histories (for example, those told in many parts of Fiji, and in Grande Terre in New Caledonia) posit a difference between the first "people of the place," the commoners or low-ranking people, from those who arrived later, the chiefly or high-ranking (see Bensa and Rivièrre 1982; Douglas I994; Abramson 2005; Jolly and Mosko I994; Jolly I994b; Sahlins I985). Still other genealogies, like those I recorded in Vanuatu in the early I970s, tell of a journey not from across the sea in a canoe but from the skyworld, and suggest that the first human beings were all men (Jolly I994a, I4 I-I43; see also Taylor forthcoming).

In all these places, in many variants, such stories of creation, of first and later arrivals and of movements of ancestors across the land-in settlement and cultivating gardens - are the basis of contemporary claims to land. In such genealogies the relation between people and place is posited not as "ownership" or human possession but as mutual possession. The land is seen as active not inert, as possessed of people, living and dead. This imbrication of body and land is palpable in language and in corporeal practice. In many Austronesian languages, the word for land (whenua, fanua, vanua) is the same as that for placenta, and a person's attachment to place is secured by the planting of the placenta soon after birth. Of course the potential for embodying this connection to land today differs dramatically across the Pacific between those independent states (like Papua New Guinea, the Solomons, Vanuatu, and Fiji) where customary land and sea custodianship prevails and those colonies (like Hawai'i, New Caledonia, and Aotearoa/New Zealand) where the claims of the first people of the place are in tension and sometimes violent conflict with those of later settlers or migrants. ${ }^{11}$

\section{Polynesia, Melanesia, Micronesia}

Indigenous genealogical plots of connection and difference across the Pacific were challenged early on by another genealogy of European origin: 
ethnological typology (compare Linnekin and Poyer 1990). From the late eighteenth century, European observers discerned important differences among the "nations" of the South Seas, differences of race and differences of place. In the writings of J S C Dumont d'Urville in I 832 and G L Domeny de Rienzi in I836-I837, such differences were categorized as Polynésie, Mélanésie, and Micronésie. ${ }^{12}$ In a map of Océanie published in I 854 (attributed to Emile Levasseur, but based on Dumont d'Urville's writings), the boundaries between them are accentuated, with hand coloring (figure 3). ${ }^{13}$ These ethnological labels have been persistent. The meanings of the words have shifted, but the way in which ethnic differences are connected with geographic location and with political and moral cartographies is more constant.

This is obvious from the first foreign attempts to plot differences among the "isles of the South Seas." Europeans developed racial and cultural typologies that-although they never marked borders patrolled by the protocols of immigration, like nation-states-formed imagined boundaries in their typification of "like peoples." Such typologies were patently predicated on a presumption of the superiority of European races and cultures; the Europeans plotted the peoples of the Pacific at various removes from themselves and, thus, from each other. This is clear, even in the more inchoate and uncertain constructions of the late eighteenth century, such as those developed by the Forsters, which were more open to modification in the light of events and contingent and changing experiences (see Jolly I992; Douglas 2006).

Let us look more closely at J R Forster's Observations (I778, I996), a text that differs from most of the others from Cook's voyages, which are rather based on daily diaries and logs, contemporaneous and recollected narrative accounts, plotted by the spatiotemporal coordinates of a journey. Forster's is a different genre - the de-temporalized, de-spatialized, seemingly disembodied writing of the philosopher and the ethnologist. It combines the authority of "being there" (central to the literature of the grand tour in Europe and travel beyond) with the claim to scientific objectivity and detached contemplation assumed by the late eighteenth century philosophers (see Jolly I 997; Thomas I996, xxv). It is a "natural history"; Forster's comments on the varieties of peoples lie beside other reflections on the "natural varieties" of the Pacific: of flora and of fauna, the formation of the land and the ocean, volcanoes, icebergs, and waterspouts.

In this huge and extraordinary tome, Forster established a gradation of the Pacific peoples visited on Cook's second voyage. He contrasted two 
"great varieties" or races: "the one more fair, well limbed, athletic, of a fine size, and a kind benevolent temper; the other, blacker, the hair just beginning to become woolly and crisp, the body more slender and low, and their temper, if possible more brisk, though somewhat mistrustful" (Forster I778, 228; Forster 1996, I 53). This contrast was complicated by a series of internal gradations. In the first group, in descending order, he ranked Tahiti and the Society Islands, the Marquesas, the Friendly Isles (Tonga), Easter Island (Rapa Nui), and New Zealand (Aotearoa). In the second, again in descending order, are New Caledonia, Tanna, and Malakula, the last two being islands in an archipelago Cook named the New Hebrides, now Vanuatu. ${ }^{14}$ I should stress that Forster's typology was developed before Cook visited Hawai'i on the third voyage and excludes not only those islands but also many others of the northern and western Pacific, later classified as Micronesia (which I do not consider here, but see Hanlon I998, 2006).

Although Forster's racial typifications anticipated the nineteenth-century labels of Polynesia, Melanesia, and Micronesia, they were not just precursors to the harder racialist science and evolutionism of that later epoch. Physical characteristics-the colors and contours of bodies, the shapes of faces, and the textures of hair-were important to Forster, but these were seen not so much as immutable essences but rather as more changeable, subject to climate and latitude, to modes of living, labor, and producing food, and to the people's degree of vigor or indolence (see Jolly I992, Douglas 2006). At certain points he portrayed the Māori, and those of the South Island especially, as "slipping down" from others in that first race, because they were dislocated from the benign warmth of the tropics to the austerity and cold of the southern islands (Forster 1996, I92). But their degeneration was also seen as the result of their social deprivation: remote from their ancestral origin, unable to use past wisdom, and, especially in the sparsely inhabited South Island, deprived of the benefits of creativity and education that Forster derived from the density of human company (Forster I996, I98; but see also Thomas I997b). ${ }^{15}$

Thus, Forster's racial plots entailed both a progressive movement toward civilization, and another movement, one of degeneration rather than devolution. But they were still racial plots, ranking peoples in temporal stages, and associating the social stages of savagery, barbarism, and civilization with infancy, adolescence, and adulthood. So, even if European Enlightenment scholars debated the nature of nature, the fate of civilization, and its propensity for corruption, they were usually confident in their own superi- 


\section{(1) $\mathbb{C}$ 迎}

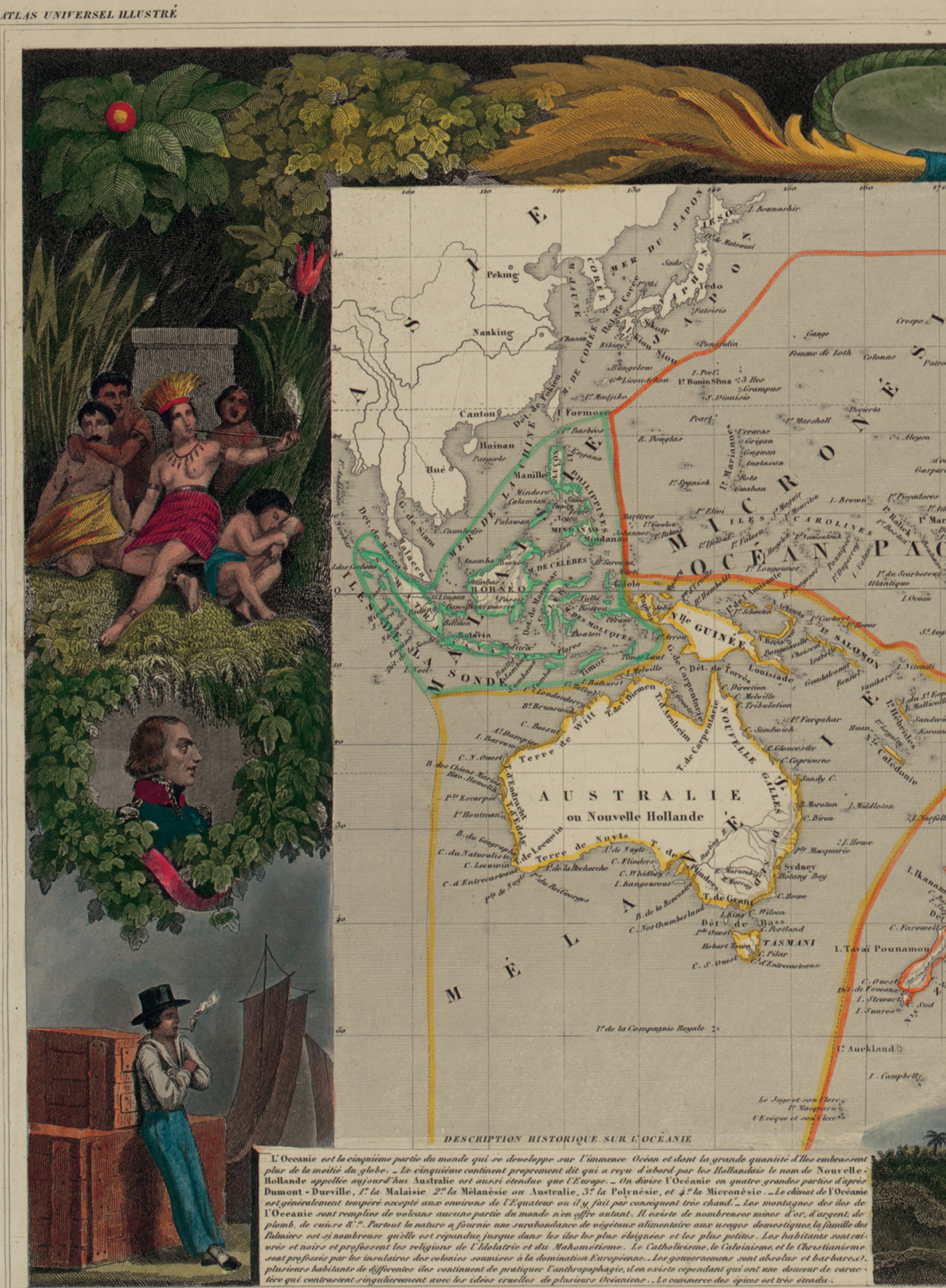

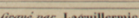

Figure 3. Map of Océanie after D’Urville’s ethnic divisions, from Levasseur i 854. 


\section{A I I I}

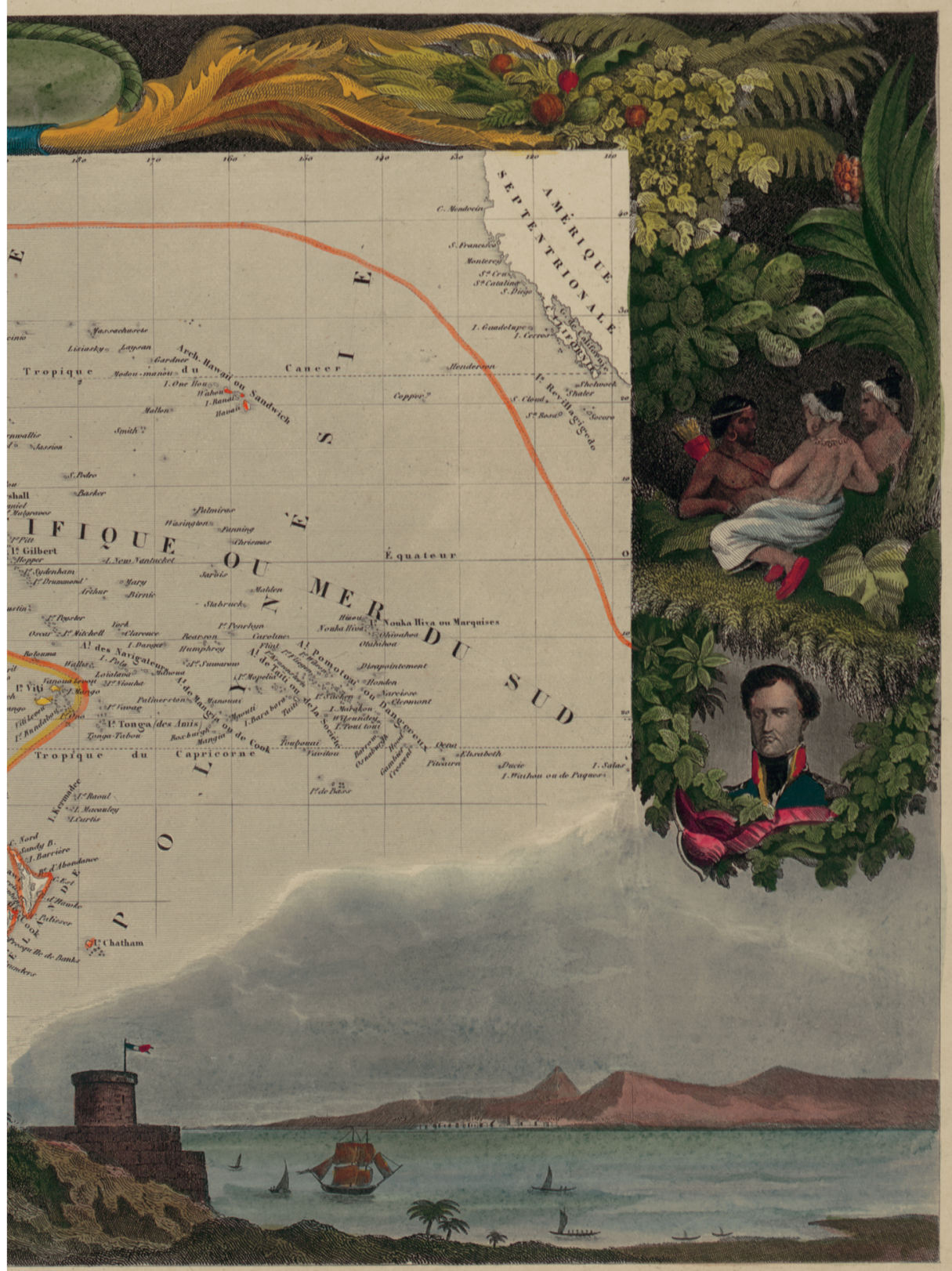

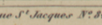

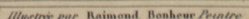

A Paris, chez A.Combette Fiditeur. Rue

Reproduced courtesy of National Library of Australia (MAP NK 2456/79B). 
ority as "adults" overseeing the growth or degeneracy of other races. And so I read Forster's creating of racial hierarchies not as the disembodied science that it purports to be, but as an exercise in embodied license, in tasteful curiosity. He charted aesthetic gradations from the ugly and gloomy Malakulans to the beautiful and felicitous Tahitians. ${ }^{16}$

As I have argued elsewhere (Jolly I992, I993, I996, I997), representations of women were critical to Forster's racial typologies, which linked contemporary "others" in the Pacific with postulations about Europe's own past, "the ancients," and prospective future. "Woman" was the sign and prophetic index of the passage from savagery to civilization, just as she was the sign and portent of the dangers of opulence, corruption, and overheated commerce in Europe itself. Pacific women were both index of hope and portent of danger, in the uncertain path toward "progress" that these explorers charted. Bernard Smith has suggested that the representation of women's beautiful and accessible bodies, as much as the rapturous rendering of landscape, evoked an image of Tahiti as Arcadia; yet, simultaneously, women's alleged lasciviousness and their sexual commerce with foreign men evoked the dark side of that island (I985, 44-47). But the ambiguous potency of the figure of woman is even greater if we consider not just Tahitian women but also the women from other parts of the Pacific with whom they were regularly compared and contrasted.

Not all Pacific women were represented in the same way. In very general terms, the differences form along a border between east and west. ${ }^{17}$ The women of the eastern islands-and especially Tahiti and Hawai' $i$-were represented as beautiful, sexually alluring, "lascivious ladies," who did refined work and were revered and elevated-perhaps too elevated for the sensibilities of European men. The women of the western islands-especially Tanna and Malakula (in the New Hebrides, now Vanuatu), and to a lesser degree, New Caledonia-were depicted as ugly, sexually unappealing, and sexually sequestered "beasts of burden," cruelly oppressed by men. This contrast in beauty, erotic appeal, and power is seen most starkly in the representations of sexual liaisons with European men, which were frequent in Hawai'i, Tahiti, and Tonga, rarer in Aotearoa/New Zealand, and absent in New Caledonia and the New Hebrides (Vanuatu). This difference is typically explained by recourse to the subjectivity of the women involved: At the eastern extreme, Pacific women are portrayed as lasciviously leaping into the sea and onto the ships, fully licensed with agency and sexual desire, whereas at the western extremities they are depicted as either being forcibly kept back from the beaches or being coerced into 
prostitution in exchange for hatchets, nails, cloth, or beads. The contrasting figures are those of subjects and objects, agents and victims. The position of women is seen, as it often was and is, as an index of civilization, but indigenous women's agency is even portrayed as catalytic to the process of the "passage" to civilization (for illustrations and further argument, see Jolly 1993; compare Guest 1996; see Tcherkézoff 2004a and $2004 \mathrm{~b}$ for more recent, dedicated deconstructions of the myth of Polynesian women's sexual hospitality; see also O'Brien 2006).

Later ethnological typifications by explorers, missionaries, and ethnographers deployed other criteria to distinguish Polynesians and Melanesians (see Thomas I997a) - the development of material culture, the openness or closure to foreign influences, and in particular the degree of political hierarchy. Twentieth-century anthropologists may have eschewed the racial basis of that classification, but ethnic plots were still insinuated in talk of cultural evolution or development. Thus an early and influential paper by Marshall Sahlins plotted a contrast between the "chiefs" of Polynesia and the "big men" of Melanesia (1963), a contrast that much later research has queried, on empirical and theoretical grounds (Douglas I979; Jolly I987; Jolly and Mosko I994). Sahlins's formulations, though more ironic than Forster's, are similarly imagined through the lens of European history, although, as I have remarked in an earlier publication (I987), in Sahlins's imagining of the Polynesians as "feudal" and the Melanesians as "capitalist," there is a devolutionary subplot to the cultural evolutionary plot that suffused his work during this period.

Despite much recent critical commentary and deconstructive effort (eg, Thomas I989; I997a; Clark 2003), maps with such tripartite divisions between Polynesia, Melanesia, and Micronesia regularly appear in the texts of anthropology, history, and linguistics, as well as in the visual displays of museums, in ways that tend to essentialize and naturalize ethnic difference. For instance, here is a version of a map of "culture areas of the Pacific," currently provided by the Center for Pacific Island Studies at the University of Hawai'i (see figure 4).

Moreover, the terms are deployed in the self-designations and claimed identities of Pacific peoples — "the Melanesian way," "the Polynesian triangle," "the Micronesian world." 18 As grounds for identity they are no doubt less salient for most Islanders than place of origin, language, and nation. But in the language of the educated, of political and cultural elites at regional meetings, and in the articulated identities of migrants, they are more important. As Albert Wendt noticed (I999, 400), such typifications 


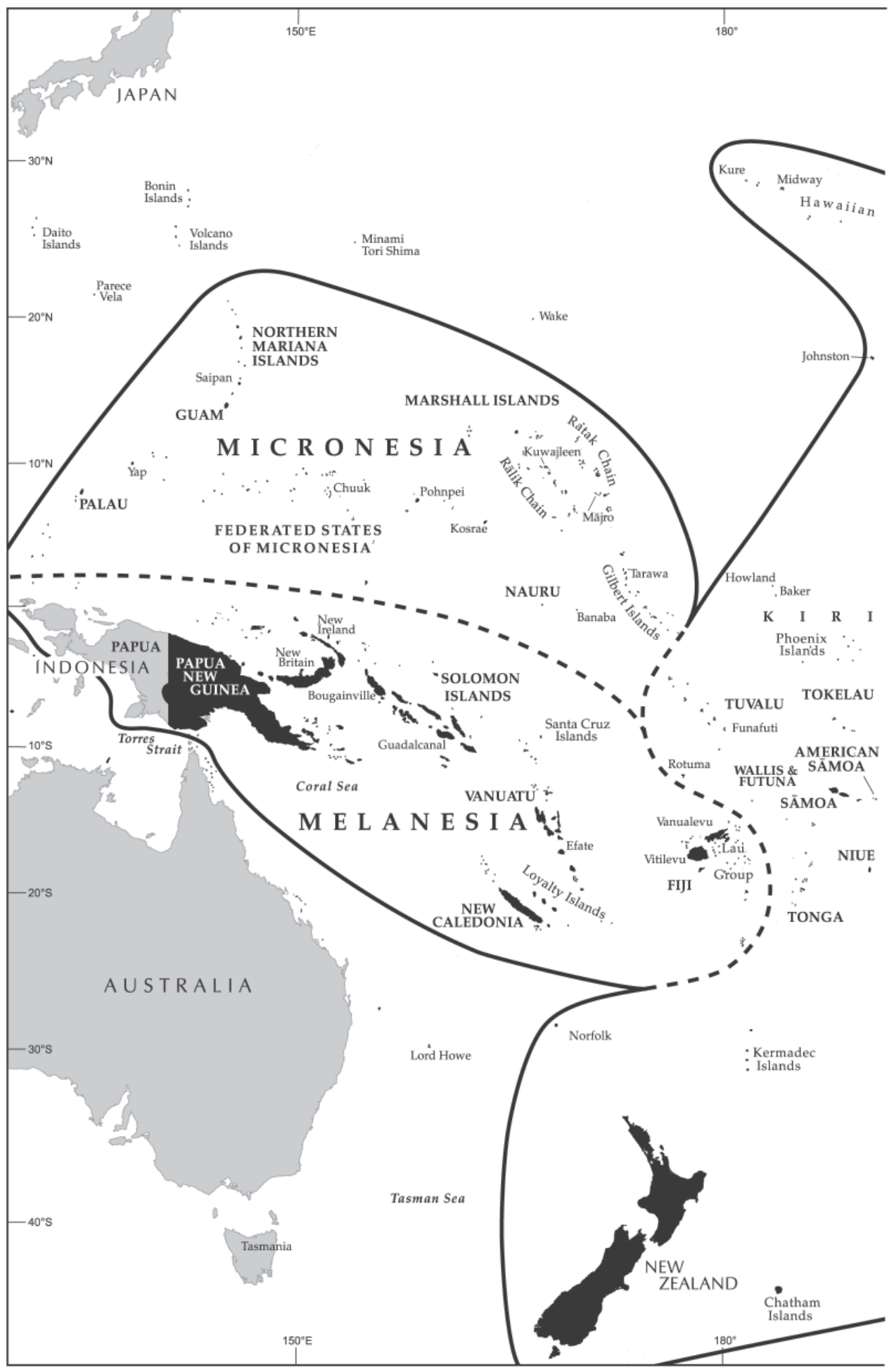

Figure 4. 


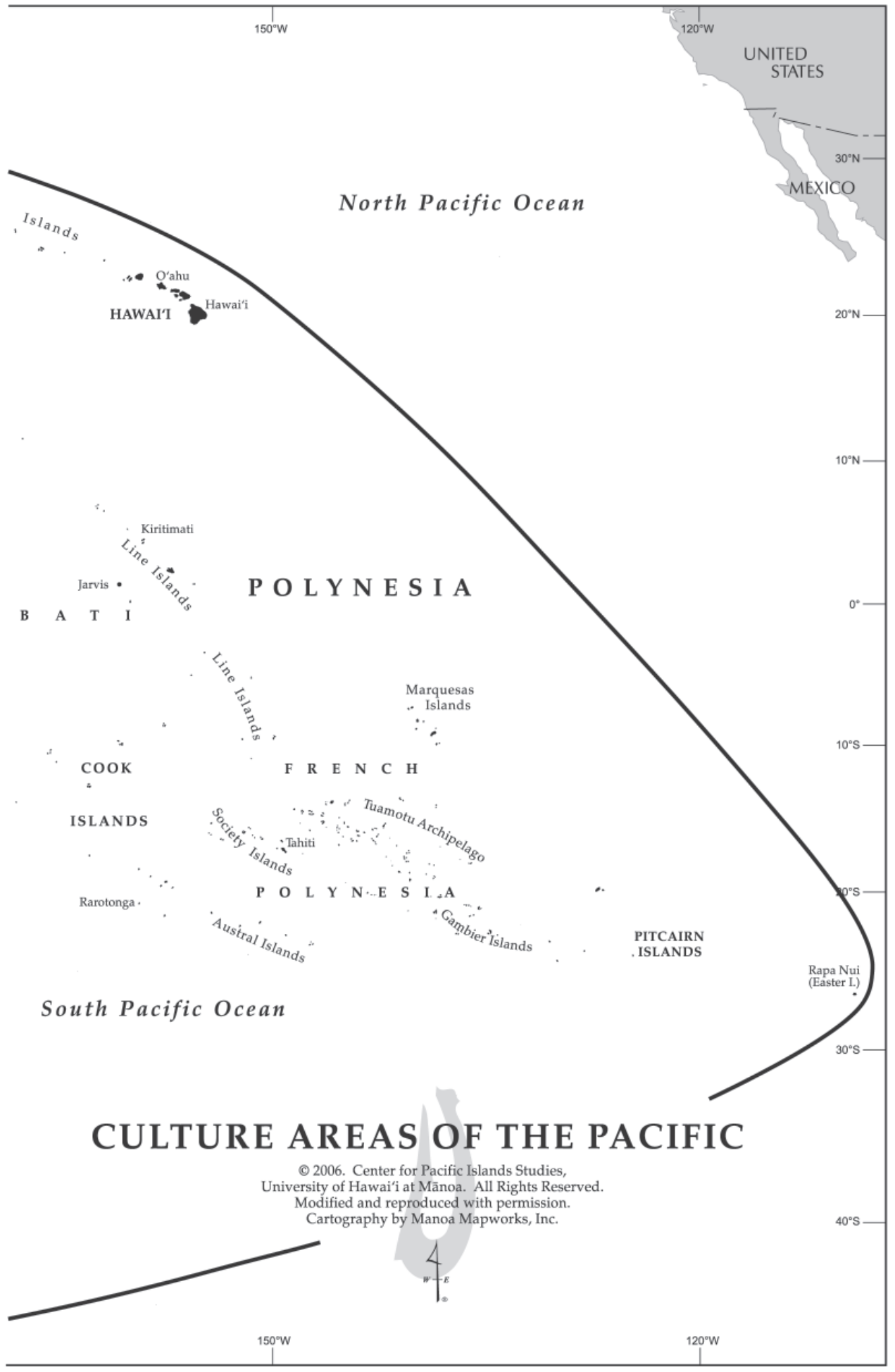


are sometimes accompanied by presumptions of hierarchy or superiority, typically on the part of Polynesians. South Pacific Festivals of Arts, he observed, have not always been benign celebrations of Oceanic culture but have also been occasions for reinscribing such hierarchical differences. He remembered how some Samoan elders present at the first South Pacific Festival of Arts in Suva in I97 I laughed at and even scorned ni-Vanuatu men from Malakula for their "primitive" Melanesian costumes - bark belts and nambas (penis wrappers). (See Hereniko 2006, 35, for a similar incident at the Cook Islands festival in I992.)

The denigrations of such ethnic hierarchies have been subverted, for example, in the writings of Bernard Narokobi (I980), Papua New Guinean lawyer and politician, in the period soon after PNG independence. His depiction of "the Melanesian way" as a "total cosmic vision of life" was both philosophical celebration and nationalist tract. He vaunted the smallness, the connecting communalism, and the spirituality of the indigenous in opposition to the large scale, the anonymous individualism, and the materialism of an imagined West (see Otto I 997). But, although Narokobi constructed Melanesian values as the antithesis of Western, he did not critically engage the detail of earlier foreign typifications, but rather gave a new, positive, alternative meaning to "Melanesian." ${ }^{19}$ Other Islanders have been more sardonically subversive of the language of ethnic types. For the opening of the Tjibaou Cultural Center in New Caledonia in I 998, Māori sculptor Brett Graham exhibited his beautiful troika, Three Standing Stones or Melanesia, Polynesia, Micronesia. Melanesia is the red one (made of stone from India). These three stones were inspired by a sense of regional connection in the common heritage of Lapita pottery. The stones were broken and reassembled like shards found by archaeologists. Said Graham, "I split the stones and put them back together again as a metaphor for the destruction and reconstruction of these cultures" (quoted in Kasarherou and Mozziconacci I998, 90; see image reproduced in Jolly 200I b, figure 9, 438).

\section{“Framing The Islands"-Regions And Rims}

I now turn from a discussion of the way in which differences have been plotted within the Pacific to the way in which differences have been imagined between the "inside" and the "outside" of the Pacific, between the "region" and the "rim." I use Greg Fry's telling phrase to suggest how in any image of Oceania there is always a "frame," an "edge" (I996), and 
to highlight how, as with photography, the point of view is crucial. Any map of the Pacific or Oceania charts what is inside and what is outside. This is nowhere clearer than in that contested notion of the "Pacific Rim," those countries-maximally North and South America, Asia, and Australasia-that edge the Pacific. These are seen through such discourses to be both its geographical limits and its commanding heights-the high ground of strategic economic and geopolitical interest and of moral presumption. I will talk in a moment about one such high ground-Australia. But let me start with a brief allusion to the debates about Pacific Rim discourse as it developed in the United States.

Arif Dirlik was the first to point out the distinctly American origins of the idea of the "Asia-Pacific" (I992), and he has clearly been central in developing a critique of the associated notion of the "Pacific Rim" (Dirlik 1993; Wilson and Dirlik 1995). But I here draw rather on a paper in the latter volume by Chris Connery (first published in 1994), which argues that the idea of the Pacific Rim emerged in the mid-I970s and was dominant in the US geo-imaginary until the I980s. In Connery's view, it is a discourse not just appropriate to but "determined" by its epoch-a particular stage of "late capitalism" and the "late cold war" years when the socialist bloc remained the strategic "other." Pacific Rim discourse is, he contended, not an "othering" discourse (like orientalism or cold war geo-imaginaries) but one predicated on equivalence through proximity, alliance, even similarity.

Moreover, for Connery, the idea of the Pacific Rim presumes neither a center nor a fulcrum of power, although he later in the same article argued that its psychic center is the United States-Japan relation, and that China was crucial in "the mythic construction of the Pacific Rim as telos" (Connery 1994,32 ), presumably in providing the scene for the rapprochement of the United States and Japan. He stressed that this was a period when United States hegemony was doubted in a way unique in the postwar era; its defeat in Vietnam, the ascendancy and threat of Japan as a global power, and the economic decline of the I970s all contributed to such doubt.

Connery explored the complicated ways in which space and time are imagined in the languages of late capitalism, with modernization theory deploying the language of temporal teleology (such as "latecomers"), which, he argued, displaced or obliterated spatial languages (of "remote" or "backward" regions) (I994, 34). As I see it, the spatial and temporal languages are co-present and complicit. Following Arturo Escobar (I995), we might note the earlier spread and rapid "naturalization" of the spa- 
tiotemporal regions of "developed" and "underdeveloped," "First" and "Third World," "North" and "South." Connery further suggested that the new realities of the Carter and Reagan years erased that temporal teleology: Japan and the East Asian "newly industrialized countries" (NICs) were no longer "the West's past" but perhaps even in its future, the telos of transformative capitalism. In this strategic circumstance, US scholars and politicians are seen to develop a discourse of equality and connectedness for this new "coprosperity sphere," especially with the first tier of nations on the rim (Japan and East Asian NICs), but even with the second tier (Thailand, Malaysia, Indonesia, coastal China). ${ }^{20}$ Their connection and similarity is imagined through the naturalized vision of "free trade," an open world market, which finds its preferred locale not in landlocked Europe but in the Pacific Ocean.

The idea of a Pacific Rim had a further advantage: it centered on an ocean. Water is capital's element. . . . The bourgeois idealization of sea-power and ocean-borne commerce has been central to the mythology of capital, which has struggled to free itself from the earth just as the bourgeoisie struggled to free itself from tilling the soil. Movable capital is liquid capital, and without movement, capital is a mere Oriental hoard. (Connery I994, 40)

This imparts new meanings to the processes of navigation and the dialectics of settlement and movement! I could further elaborate Connery's extraordinary analysis of this ideology of the Pacific Rim, ${ }^{21}$ but, rather, at this point I want to suggest how this vision (and perhaps even his analysis of it) occludes the "inside" of the Pacific. The ocean has become not an American lake but a lack, a hole, like the proverbial hole in the donut (compare Hau'ofa I994). And those who live in the Pacific, the Islanders, are not imagined as part of that sphere.

I now turn from this peculiarly American vision of the "Pacific Rim" to the peculiarly Australian vision of the "Pacific region." This is not to suggest that Pacific Rim discourse has not been heard in Australia. It has, especially in the pronouncements of economists and political scientists in the I970s and I980s, but it was and is subordinated to the discourse of the "Pacific region." This seems geopolitically rather than geographically determined. Australia is no global power, but as a regional power it presumes a special privileged relation to the Pacific and acts not just as ally but often as proxy to US imperial interests.

In my discussion of Australian visions of the Pacific region, I am heavily indebted to the work of Greg Fry (I996), who analyzed how, from the 
mid-I980s to mid-I990s, the islands were "framed" by Australian government and academic discourses, not like Asia as the future promise of capitalism, but as its terminus-its doomsday. ${ }^{22}$ Fry discerned a "doomsday scenario" in Australian academic and policy discourses about the Pacific in the decade prior to his writing. In this nightmare vision, the region is seen in danger of "falling off the map." Its proponents warn about failures of development as measured by gross domestic product; "soaring populations"; unsustainable exploitation of resources; the marginalization of Island economies with globalization; and the withdrawal of powerful aid donors with the end of the cold war. If the nightmare cannot be averted, then overpopulation, poverty, unemployment, ecological devastation, and declining health will surely ensue. To avoid the doomsday path, Island states need to open their economies; effect structural change and good governance; abolish customary land tenure and inappropriate, undemocratic traditions; and connect with the dynamism of Asia. Such diagnoses and remedies saturated not just the speeches of Labor government ministers like Gordon Bilney, but the views of many bureaucrats, academic economists, and demographers as well as some journalists (most notably Rowan Callick, writing in the National Centre for Development Studies publication, Pacific 2010, in I993). In such writings, Australia is cast both as model and savior of the Pacific, its future and its prophet.

But, as Fry argued so persuasively, much of this is hyperbolic rhetoric, reliant on dubious statistics and partial knowledge. Important dimensions of Pacific experience are omitted-such as the continuing centrality of subsistence economy. This is not easily included in the commodity accounting of gross domestic product, and moreover is grounded in customary land tenure, which is seen in this view as an obstacle to "development." The assessment of a poor or stagnant economic performance is based on uncertain data. The specter of overpopulation is overdrawn-with the experience of one or two countries, most notably Papua New Guinea and the Solomons, being extrapolated to the region as a whole. I have criticized this particular specter in far more detail elsewhere (Jolly 200Ia), suggesting not just that it is overgeneralized (compare Underhill-Sem I994), but that it is historically vapid, ignoring the prior ghost of Pacific depopulation and ascribing the causes of overpopulation to the allegedly natural regimes of indigenous fecundity rather than locating its more likely origins in the transformation of the reproductive lives of Islanders consequent on their conversion to Christianity and the effects of colonizing capitalism.

Although the ecological degradation of mining, logging, and fishing in 
the Pacific region might induce greater cause for alarm, in the diagnoses of these doomsday prophets, the blame is most often attached to venal local interests and rapacious Asian companies (Malaysian logging firms, Japanese and Korean tuna boats), while Australia's own extensive interests in mining in several countries are passed over in relative silence.

This doomsday scenario was much criticized, not just by Fry and other academics, but by several Island prime ministers at the time, including Sitiveni Rabuka of Fiji, Paias Wingti of Papua New Guinea, Solomon Mamaloni of Solomon Islands, and Geoffrey Henry of the Cooks, as well as the then president of Fiji, Ratu Sir Kamisese Mara (Fry I996, 4). But, arguably, the scenario has not gone away, and Australian talk of Pacific "crisis" has been strengthened in recent times by the heightened fear of fragile or "failed" states, violent coups, and secessionist movements- the war in Bougainville, the Sandline crisis in Papua New Guinea, the several coups in Fiji, the conflict between Guadalcanal people and Malaitans in the Solomons, and the prospect of continuing bloody events in West Papua, as well as the specter of continuing refugee streams from there and elsewhere. ${ }^{23}$ In Australia, the southwest Pacific has been frequently described in the talk of defense analysts, politicians, and journalists as "an arc of instability" (see May 2003). Such talk has pervaded the public imagination of the Pacific in Australia since the turn of the twenty-first century. The events that unfolded after George Speight and his followers invaded Fiji's Parliament on I9 May 2000 were headline news for weeks in Australia. Some Australian politicians were forthright in their condemnation of the coup leaders as "terrorists" and in their calls for the restoration of democratic government in Fiji and the equality of all citizens, regardless of race. Threats of bans and boycotts from Australia were consequential in the unfolding of events, especially after the release of the hostages. Australian politicians' language and actions in this period were criticized before the United Nations by the interim prime minister of Fiji as a new form of imperialism. And although the unfolding events of the Fiji coup of 2006 led by Commodore Bainimarama have not attracted such consistent attention in the Australian media, he was able to capitalize on the proximity of Australian warships, ostensibly sent to evacuate Australian citizens, to warn the Australian government against intervention. In the event, Prime Minister John Howard eschewed such intervention, suggesting that Australian forces would not be seen fighting on the streets of Suva, intervening in what was an internecine struggle among Fijians. Such logic did not deter Australia from intervention in Solomon Islands or East Timor, albeit 
at the request of prevailing or prospective governments in those countries (see Charlesworth 2006).

Although sensitive to such accusations of neocolonialism, Australia has in the last decade become far more interventionist in the southwest Pacific, not just in relation to its erstwhile colony, Papua New Guinea, with whom it still proclaims "a special relationship" (see Denoon 2005), but also in several other countries of the region, most notably Solomon Islands through the Regional Assistance Mission to Solomon Islands, or RAMSI (see Kabutaulaka 2005; Fraenkel 2004; Moore 2004). Although some have seen this as mirroring the preemptive strategy of the US-led invasion of Iraq in 2003 , justified as deflecting future threats and establishing democracy and human rights, Australia's presumption to represent and influence events in the lives of near Pacific Islands primarily derives from its role as "neighbor," military ally, economic investor, trade partner, and aid donor. It is not alone in this, of course: Americans, Canadians, the French, New Zealanders, the Japanese, and increasingly the Chinese are engaged in similar ways. But the Pacific seems more focal in the imperialist imaginaries and development dreams of Australia. And in this region, as in Asia, Australia locates itself ambiguously as both inside and outside the region. In the Australian colloquialism, it is "our backyard."

\section{“Our Sea Of Islands"-Epeli Hau'ofa's Alternative Vision}

I now consider very briefly the writings of Epeli Hau'ofa, whose alternative vision of Oceania has proved especially influential (I994, I998, 2000). His new vision was created in defiance of the languages of colonial partitions, the borders created by the ethnological typifications of Melanesia, Polynesia, and Micronesia, and in resistance to the discourses of developmentalism that typically imagine the Pacific as a proliferation of small states characterized by isolation, deficiency, danger, and doom (as in Australian doomsday scenarios discussed earlier). Since I have already discussed Hau'ofa's alternative vision in detail in the pages of this journal (Jolly 200Ib), I will be brief. But I do need to reiterate how he writes against the orthodoxies of foreign experts and especially those economists emanating from the World Bank and the Australian National University who constantly typify the Pacific in terms of what it lacks: not only the palpable absence of development or growth, but the deficiencies of scale, isolation, and dependency-small islands, with tiny populations, remote 
from world centers but increasingly dependent on them. What Hau'ofa has rather stressed is the connecting sea-how, despite the diversities of languages and cultures, there is an ocean of connection among Islanders.

Moreover, Hau'ofa has argued that besides the privileged relationship between Islanders and Outlanders, between indigenous and the foreign representations of the Pacific, we must ponder the relations between Islanders living "inside" and "outside" the Pacific. Those "outside" include large numbers of Hawaiians who are living elsewhere in the United States (see Kauanui 2005); the large diasporic communities of Tongans, Samoans, Cook Islanders, and Niueans in Aotearoa/New Zealand, Australia, and North America; some smaller communities of Micronesians overseas; and, increasingly, Indo-Fijians who, in the wake of the Fiji coups, have increasingly emigrated to New Zealand, Australia, and North America (Pangerl nd). They also include descendants of South Sea Islanders who migrated to labor on nineteenth-century plantations, who are living in Australia, New Caledonia, and Sāmoa. In such migrations from the nineteenth to the twenty-first century, the peoples of Oceania have again become world travelers. And in the process of resettling they have had to establish relations not just with dominant white settlers but also with the indigenous peoples of these several nation-states. In some places, like Hawai'i and Aotearoa/New Zealand, this has tended to situate Pacific peoples as "natives" or "migrants," as indigenous or diasporic, as "rooted" or "routed" (see Clifford 1997), rather than as sharing a deep genealogy of cultural and historical connection-the great Ocean of Hau'ofa's vision.

Hau'ofa aspires to embrace all these places in his expanded world of Oceania (Jolly $200 \mathrm{Ib}, 425$ ). This expanded world not only blurs the boundaries of nation-states but also emphasizes the connections between Islanders beyond and within nation-states. In such a vision the relation between Islanders is seen as more independent of their relation to white settlers or Europeans (see Jolly nd b). So, Teresia Teaiwa and Sean Mallon have suggested an "ambivalent kinship" between Māori and Pacific Islanders in Aotearoa/New Zealand, not so divided as "natives" and "migrants" and in differential relation to Pākehā and the nation-state, but connected, not just by ancient pasts but also by contemporary cultural affinities and kinships (2006).

In his innovative project of establishing the Oceania Centre for Arts and Culture on the campus of the University of the South Pacific (figure 5), Hau'ofa has emphasized not so much the differences among Islander student populations and others resident in Suva-indigenous and Indo-Fiji- 


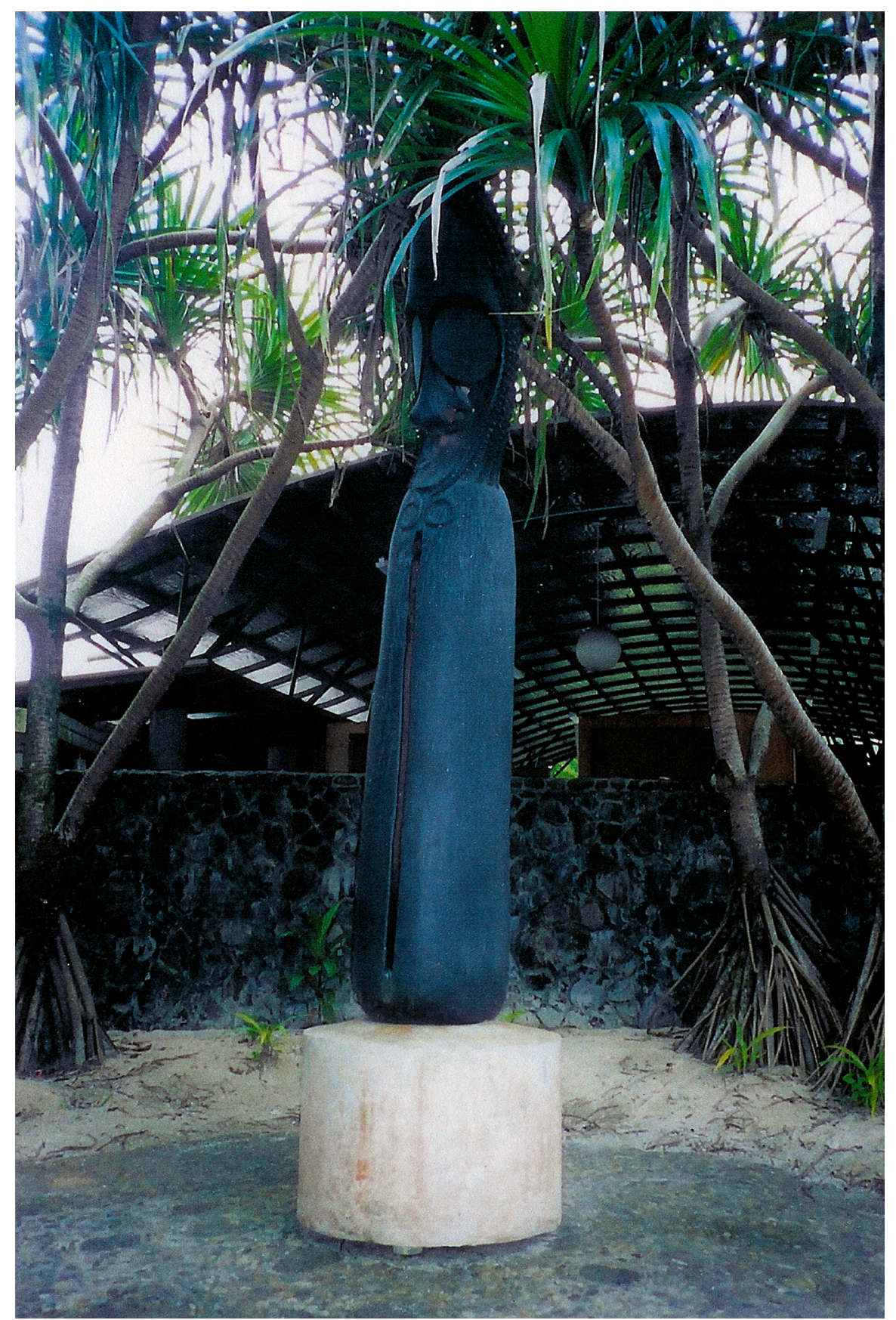

Figure 5. Slit gong from Ambrym, Vanuatu, outside the Oceanic Centre for Arts and Culture, The University of the South Pacific. Photograph by Margaret Jolly, 8 July 2006. 
ans, Solomon Islanders, Tongans, Samoans, I-Kiribati, Banabans, and so on-but rather their affinities and relations. Through the visual and performing arts, he is fostering a sense of connection, exchange, and mixing more profound than that typically performed in national or regional plots of "unity in diversity" (see Jolly 2005). This stress on creative exchange among Islanders is especially clear in the brilliant choreography of Allan Alo and his dancers, in the Oceanic music of groups like Sound Waves, based in Suva, and the explosion of creativity in the visual arts under the present direction of that hugely talented artist and writer, John Pule (see Hereniko 2006).

\section{Conclusion}

This paper has offered a summary survey, or as Australians would say, a "Cook's tour." I hope I have suggested both continuities and ruptures in the relation between indigenous and foreign representations of the Pacific. They emerge as separate, alternative, even opposed visions, which we might telegraphically encode as genealogy versus cartography. But increasingly, with the emergent power of capitalism in both the epochs of colonialism and development, we witness a "double vision" of stereoscopy and blurred edges in "imagining Oceania." I have suggested, too, that all imaginings of the Pacific and its rim are simultaneously visions of space and time. This condensation of time and space is apparent in both indigenous genealogies and foreign cartographies or ethnic typologies, in geopolitical imaginaries of Pacific Rim and Pacific region, in the doomsday prophecies of recent Australian ideologues and the future hopes of Islander scholars, artists, and ordinary people. Finally, I should stress that it is not just the double visions of "East" and "West" from the rim that matter, but the double visions of Islanders, regardless of whether they live inside or outside the Pacific, or in between (K Teaiwa 2002), in Hau'ofa's enlarged world of Oceania.

AN EARLIER VERSION OF THIS PAPER was presented in Tokyo in 2000 as a keynote address on a panel with Arif Dirlik and Yasuo Endo at a conference organized by the Center for Pacific and American Studies at the University of Tokyo. It was subsequently published in conference proceedings, which are not widely available (see Jolly 200Ic), although some colleagues are using it in teaching. The present version has been edited (parts contracted and others expanded) and updated, and 
a number of maps and figures are included that, due to my own oversight, were not published with the earlier version. Thanks so much to Professors Daizaburo Yui and Yasuo Endo for allowing this republication.

\section{Notes}

I I cannot here address the huge literature that critically considers cartography as a modernist European knowledge saturated with power. This has been a major preoccupation especially in the writing of critical geographers. For one synthesis of some of this work, see Gregory 1994.

2 I remember vividly (as a young anthropologist working in the archipelago of Vanuatu in the early I970s) being quizzed by a young man of Bunlap (a kastom village) who had neither been to school nor exposed to Western-style maps of the world, about the disposition of the countries of Europe. Frustrated by my attempts to plot in words or explain with an atlas the geographic situation of England, France, Germany, and Spain, he asked, "But tell me, Margaret, which one is the last island?" He thus transposed a vision of the archipelago he lived in onto the countries of continental Europe.

3 My reference to Japan here relates to the context of this paper's first presentation (see acknowledgments).

4 Tupaia's name was usually spelled Tupaya in the Cook voyage materials. Anne Salmond has offered the best appraisal of Tupaia and his world to date, consummately evoking the complicated indigenous politics of rank, rivalry, and religion in which he was enmeshed and his central role as navigator and interpreter on Cook's first voyage $(2003,34 \mathrm{ff})$. As a priest of 'Oro, the war god, he was intimately involved in a violent politics of conversion, carrying his worship from island to island. See also Dening 2004, I70ff. The arioi were those men and women who dedicated themselves to 'Oro. They comprised mainly unmarried aristocratic men from the highest ari'i class, but also some ari'i women and some men and women of the median rank, ra'atira, and numbered about a fifth of the total population. They traveled around the islands like strolling players, feasting at others' expense, and performing chants and dances, theatrical farces, and satires about the chiefs. They were also reputedly sexual libertines but were proscribed from reproducing. Any offspring born to an arioi, male or female, had to be killed (Gell I993, I47). For some arioi, membership was a lifelong vocation, but others left while still young to marry and to reproduce.

5 Ethnology predates the practice of professional anthropology, as is clear from the ethnological writings of early explorers, missionaries, and colonial officials. At the point that anthropology was establishing its disciplinary credentials in the early twentieth century, some, like Bronislaw Malinowski, were keen to dis- 
tance themselves from earlier "amateur" observers, claiming both an objectivity and an expert knowledge based on fieldwork and participant observation, which allegedly made anthropologists different. Though educated as an anthropologist myself, I consider this a self-serving, shallow genealogy.

6 I here echo the phrase so associated with Donna Haraway's writing (I99I), which contends that all knowledge is situated and partial, and criticizes those who so readily associate vision with hegemonic power (as in certain facile treatments of Foucauldian notions of the panopticon-that space of the asylum where all the movements of inmates could be seen and controlled - or those who ascribe too much power to the colonial or masculinist gaze; compare Jolly 1997. Haraway insists on the embodied nature of all vision, so that we can "reclaim the sensory system that has been used to signify a leap out of the marked body and into a conquering gaze from nowhere" (I99I,I 88). Even seemingly disembodied visual technologies such as ultrasounds, computer screens, and televisions exist in complex relations to human bodies. Some authors have claimed that the new technologies like Geographical Information Systems (GIS) and the virtual realities of cyberspace are different from those visual technologies that posit the world as spectacle, since the former, through their energetic rotations and kinesthetic turbulence, radically destabilize the body of the viewer and deconstruct their power.

7 I do not want to imply by this that there was not also full-bodied knowledge in the European experience of navigation. The visual technologies of cartography were complemented by similar experiential processes, and indeed Cook and his sailors learned from Tupaia and other Islanders to discern signs of land in the appearance of land birds and changes in the patterns of seaweed and fish. See Dening I998, 2004.

8 See my fuller discussion of this (Jolly nd b). Tupaia first sketched the more familiar islands of Ra'iatea, Tahaa, Bora Bora, and Maurua. Although centered on Ra'iatea, his map traverses several thousand kilometers of the Central Pacific, from the Marquesas in the east to the Fiji group in the west. He named one hundred thirty islands, including those as far away as New Zealand (Pounamu and Teatea), Tonga, Sāmoa, Rotuma, the Tuamotus, the Marquesas, the Southern Cooks, and the Australs.

Nicholas Thomas has suggested that although “Tupaia's map has figured as a key source for subsequent inquiries into the geographic knowledge of Polynesians, its extraordinary character as a graphic document that fuses an indigenous perception of the world with the moralizing cartography of the Enlightenment has been strangely unremarked upon" (I997c, 4). Although this is true, we must still ponder the difference between the situated knowledges of eighteenth-century Polynesians and Europeans, and how far the "moralizing cartography of the Enlightenment" actually influenced indigenous views of places and peoples (see Jolly nd b). Moreover, some authors have talked about the relation between Tupaia's 
map and Cook's not so much as a creative translation between Oceanic wayfinding and European navigation but as an encounter framed by "cartographic méconnaisance" (see, eg, Turnbull I 998, I I7ff; Dening 2004). Neither Cook nor Banks recorded Tupaia's descriptions of islands, sailing directions, or the stories of settlement. Their fractured conversations were probably insufficient to allow Cooks and Banks to learn much about the complex arts of Polynesian wayfinding. We now know that Tupaia learned how to draw other things as well as this map. Tupaia has been revealed as the person who produced several drawings and watercolors, of arioi musicians with their drums, of indigenous Australian men in canoes in Botany Bay, and a sketch of an exchange of a large crayfish for white tapa between a Māori man and Banks - a delightful, iconic image that Salmond used on the book cover of Two Worlds (I997).

9 I do not mean to imply a strict separation of either peoples or languages here, since there has been much mutual influence. For some examples of mutual influences among peoples and languages, see Spriggs I 997 and Tryon nd.

Io This list in this order is not meant to suggest a clear staging of settlement. The history of these migrations and settlements is far too contested and complex to recapitulate here (but see Bellwood 1978 and Spriggs I997).

II In the independent states, land disputes are typically decided at public meetings where disputants recount rival genealogies and the more compelling orations usually win out. Land disputes have been the cause of much past and present violence in the Pacific. Note the very strong pressure from many foreign agencies of neoliberal persuasion for a transformation from customary to commoditized land tenure, although as Gregory E Rawlings has pointed out for Vanuatu (I999, 2002), long-term leasehold can be tantamount to alienation, as in the subdivisions on Efate near Pango village, and indeed across much of Efate in the last three years.

I2 I should note that the term "Polynesia" was first used by Charles de Brosse in 1756 to refer to all the islands of the Pacific. The history of the distinction between Polynesia and Melanesia and the meaning of "race" in European thought has been exhaustively researched and debated of late (see Clark 2003; Tcherkézoff 2003; Douglas 2005, 2006).

I3 Océanie also included Australia (as part of Mélanesie) and the Malay Archipelago (as Malaysie).

I 4 In admitting gradations both within and between these two classes, Forster implied a continuum but also thought that the first could be seen as one tribe with a general character. It is important to stress again that his construction did not rely on essentialist or immutable notions of race (see Douglas 2006), and, as Thomas has rightly stressed (1996), there were intersecting temporalities in Forster's plots of the Pacific. On the one hand there was a narrative of progress, and on the other, one of derivation from an ancestral origin and climatically determined adaptation. 
I 5 The Māori were also vaunted for their improved condition in relation to the inhabitants of Tierra del Fuego.

I6 These racial gradations reflect degrees of difference not just from Forster's own body but also from European ideals of beauty during this period. Although we might see the male body of the ancients as normative or ideal in eighteenthcentury Europe, the ideal that Forster formulates for the Pacific often rather prefers the feminine to the masculine form.

I7 I appreciate that this is a rather loose cartographic referent, since Aotearoa/New Zealand is rather far south, and the South Island is as far west as Vanuatu and New Caledonia. But often such spatial language is used contemporaneously to plot the differences. Moreover, I like the way the phrasing plays with the more usual contrast of West and East as Occident and Orient.

I8 I have a vivid memory of one of my indigenous Hawaiian graduate scholars at the University of Hawai' $\mathrm{i}$ in 1998 complaining, after a reading of Alfred Gell (I993), that he felt uncomfortable sitting on top of the "Polynesian pyramid"!

I9 Thomas adjudged that this cannot readily be seen as a "derivative discourse" based on European models, since the influences seem to be more from the philosophers of Negritude in Africa (I997a). Moreover, he argued, it not so much overtly resists Western typologies (since it is hardly in conversation with their detail) as it deplores the more general denigration of Melanesian as primitive or traditional.

20 Of course this hierarchy has again been vastly transformed, after the experience of crisis in Asian economies of the late I990s, the economic downturn in Japan, and the exponential growth in China and India.

2I Also compelling is Connery's rhetoric about the term "rim": "Consider the word rim, a rim unites-it unites across oceans, across ethnic and racial divides. It presumes a unity, a centeredness with no center, a totality, an unbrokenness. A rim is thin. It is stable but precarious. One can fall off a rim. A rim is a horizon, the horizon of capital, of history, of space and time" (Connery I994, 4I).

22 Fry's analysis is situated in the longue duree of Australian images of the Pacific-from the nineteenth and early twentieth century views of the "South Seas" or "the islands." Even before the federation of the several colonies as a nation in I90I, many Australians saw this region as one where they had a right or even a duty to be engaged, and which they could presume to represent, in both the sense of "speaking for" and of "portraying to the wider world." This presumption was always strongest in relation to the closer countries of the southwest-Vanuatu, the Solomons, Fiji, and especially Papua New Guinea, that erstwhile colony with which Australia has a continuing "special relationship." The presumption was determined not just by geographical proximity but also by complicated colonial histories and the particular circuits of Australian travelers, traders, planters, missionaries, colonial officials, soldiers, and development agents (Thompson I990). To combat French influence, some Australians were eager to push Britain for the 
annexation of the New Hebrides/Nouvelles Hébrides in the late nineteenth century, but with the failure of that initiative they never presumed close engagement with the remaining French colonies, such as nearby New Caledonia.

23 As I updated this article, a bill designed by the Howard government to further strengthen Australia's border security by processing "offshore" all asylum seekers arriving in Australia by boat had just been defeated by a revolt of backbenchers on the government side. This draconian legislation was seen by many as appeasement to the Indonesian government after a group of West Papuans had been granted admission to Australia in May 2006. The "offshore" destinations intended by Howard were cash-strapped islands like Nauru, site of a detention camp for many refugees from 200I, after Australia's earlier tightening of border controls and ominously referred to as the "Pacific solution."

\section{References}

\section{Abramson, Alan}

2005 Drinking to Mana and Ethnicity: Trajectories of Yagona Practice and Symbolism in Eastern Fiji. In Relations in Multicultural Fiji: The Dynamics of Transformations, Positionings and Articulations, edited by Elfriede Hermann and Wolfgang Kempf. Special issue of Oceania 75 (4): 325-34I.

Bellwood, Peter

I978 Man's Conquest of the Pacific. Sydney: Nelson.

Bensa, Alban, and Jean-Claude Rivièrre

I982 Les chemins d'alliance: l'organisation social et ses representations en Nouvelle-Caledonie (region de Toubo-aire linguistique cemubi). Paris: SELAF.

Borofsky, Robert, editor

2000 Remembrance of Pacific Pasts: An Invitation to Remake History. Honolulu: University of Hawai'i Press.

Callick, Rowan

I993 A Doomsday Scenario? In Pacific 2010: Challenging the Future, edited by Rodney Cole, I-I I. Canberra: National Centre for Development Studies, Research School of Pacific Studies, The Australian National University.

Charlesworth, Hilary

2006 Building Justice and Democracy After Conflict. Cunningham Lecture, Academy of the Social Sciences in Australia, Canberra, 2 I November.

Clark, Geoffrey, editor

2003 Dumont d'Urville's Oceanic Provinces, Fundamental Precepts or Arbitrary Constructs? Special issue of Journal of Pacific History 38 (2). 
Clifford, James

I997 Routes: Travel and Translation in the Late Twentieth Century. Harvard: Harvard University Press.

Connery, Christopher L

I994 Pacific Rim Discourse: the US Global Imaginary in the Late Cold War Years. Boundary 2:3 I-56. Republished in Asia/Pacific as Space of Cultural Production, edited by Rob Wilson and Arif Dirlik, 30-56. Durham, NC: Duke University Press (1995).

Dening, Greg

I998 Endeavour and Hokule $a$. In Readings/Writings, Ioo-I I9. Melbourne, vic: Melbourne University Press.

2004 Beach Crossings: Voyaging across Times, Cultures and Self. Melbourne, vic: Miegunyah Press.

Denoon, Donald

2005 A Trial Separation: Australia and the Decolonisation of Papua New Guinea. Canberra: Pandanus Books.

Diaz, Vicente, writer and director

I997 Sacred Vessels. Videorecording. Guam: Moving Island Productions.

Dirlik, Arif

I992 The Asia-Pacific Idea: Reality and Representation in the Invention of a Regional Structure. Journal of World History 3 (Spring): 5 5-97.

1993 What is in a Rim? Critical Perspectives on the Pacific Region Idea. Boulder, co: Westview Press.

Domeny de Rienzi, G L

I836-I837 Océanie, ou cinquième partie du monde. Revue géographique et ethnographique de la Malaisie, de la Micronésie, de la Polynésie et de la Mélanésie. Three volumes. Paris: Firmin Didot frères.

Douglas, Bronwen

I979 Rank, Power, Authority: A Reassessment of Traditional Leadership in South Pacific Societies. Journal of Pacific History I 4:2-27.

I994 Hierarchy and Reciprocity in New Caledonia: An Historical Ethnography. In Jolly and Mosko 1994, I69-193.

2005 Notes on "Race" and the Biologisation of Human Difference. The Journal of Pacific History 40:33 I-338.

2006 Slippery Word, Ambiguous Praxis: "Race" and Late-1 8th-Century Voyagers in Oceania. The Journal of Pacific History 4I:I-29.

Dumont d'Urville, J S C

I 832 Sur les îles du Grand Ocean. Bulletin de la Société de Géographie [Paris] I7 (I05).

Escobar, Arturo

I995 Encountering Development: The Making and Unmaking of the Third World. Princeton, NJ: Princeton University Press. 
Finney, Ben

I992 From Sea to Space. Macmillan Brown Lectures, Massey University. Palmerston North, NZ: Dunmore Press; Honolulu: University of Hawai'i Press.

Finney, Ben (with Marlene Among, Chad Babayan, Tai Crouch, Paul Frost, Bernard Kilonsky, Richard Rhodes, Thomas Schroeder, Dixon Stroup, Nainoa Thompson, Robert Worthington, and Elisa Yadao)

I994 Voyage of Rediscovery: A Cultural Odyssey through Polynesia. Berkeley: University of California Press.

Forster, Johann Reinhold

I778 Observations Made During a Voyage Round the World on Physical Geography, Natural History and Ethic Philosophy. London: G Robinson.

1996 Observations Made During a Voyage Round the World, on Physical Geography, Natural History, and Ethic Philosophy. New edition, edited by Nicholas Thomas, Harriet Guest, and Michael Dettelbach. Honolulu: University of Hawai'i Press.

Fraenkel, John

2004 The Manipulation of Custom: From Uprising to Intervention in the Solomon Islands. Canberra: Pandanus Books.

Fry, Greg

I996 Framing the Islands: Knowledge and Power in Changing Australian Images of “The South Pacific.” Working Paper I996/5. Department of International Relations, Research School of Pacific and Asian Studies, Australian National University. Slightly expanded and republished in The Contemporary Pacific 9:305-344 (I997), and in Voyaging through the Contemporary Pacific, edited by David Hanlon and Geoffrey $\mathrm{M}$ White, 25-63. Lanham, MD: Rowman \& Littlefield (2000).

Gell, Alfred

I993 Wrapping in Images: Tattooing in Polynesia. Oxford: Clarendon Press/ Oxford University Press.

\section{Gregory, Derek}

I994 Geographical Imaginations. Cambridge, MA: Blackwell.

Guest, Harriet

I996 Looking at Women: Forster's Observations in the South Pacific. In Forster I996, xli-liv.

Hanlon, David

I998 Remaking Micronesia: Discourses over Development in a Pacific Territory. Honolulu: University of Hawai'i Press.

2006 The "Sea of Little Islands": Examining Micronesia's Absence from "Our Sea of Islands." Paper presented at the Pacific History Association Biennial Conference, University of Otago, Dunedin, 7-10 December. 
Haraway, Donna

I99I Situated Knowledges: The Science Question in Feminism and the Privilege of Partial Perspective. In Simians, Cyborgs, and Women: The Reinvention of Nature, I83-20I. London: Routledge.

Hau'ofa, Epeli

I994 Our Sea of Islands. The Contemporary Pacific 6:I48-I6I. First published in A New Oceania: Rediscovering Our Sea of Islands, edited by Vijay Naidu, Eric Waddell, and Epeli Hau'ofa, 2-I6. Suva: School of Social and Economic Development, University of the South Pacific (I993).

I998 The Ocean in Us. The Contemporary Pacific I0:39I-4IO.

2000 Epilogue: Pasts To Remember. In Borofsky 2000, 45 2-47 I.

Hereniko, Vilsoni

2006 Dancing Oceania: The Oceania Dance Theatre in Context. In The Fifth Asia-Pacific Triennial of Contemporary Art, edited by Lynne Seear and Suhanya Raffel, 32-4I. Brisbane: Queensland Art Gallery Publishing.

Hetherington, Michelle

200I Cook and Omai: The Cult of the South Seas. Canberra: National Library of Australia, in association with the Humanities Research Centre, The Australian National University.

Jolly, Margaret

I987 The Chimera of Equality in Melanesia. Equality and Inequality: Papers in Memory of Chandra Jayawardena. Special issue of Mankind I7 (2): I 68-I 83 .

I992 "Ill-natured Comparisons"? Racism and Relativism in European Representations of ni-Vanuatu from Cook's Second Voyage. In Colonialism and Culture, edited by Nicholas Thomas. Special issue of History and Anthropology 5 (3-4): 33 I-364.

I993 Lascivious Ladies, Beasts of Burden and Voyaging Voyeurs: Representations of Women from Cook's Voyages in the Pacific. Paper presented to Ninth David Nichol Smith Memorial Seminar, "Voyages and Beaches, Discovery and the Pacific I700-1840," University of Auckland, New Zealand, 24-28 August.

I994a Women of the Place: Kastom, Colonialism and Gender in Vanuatu. Chur, Switzerland: Harwood Academic Publishers.

I994b Hierarchy and Encompassment, Rank, Gender and Place in Vanuatu and Fiji. In Jolly and Mosko I994, I33-168.

I996 Desire, Difference and Disease: Sexual and Venereal Exchanges on Cook's Voyages in the Pacific. In Exchanges: Cross-cultural Encounters in Australia and the Pacific, edited by Ross Gibson, I87-217. Sydney: Museum of Sydney and Historic Houses Trust of New South Wales.

I997 From Point Venus to Bali Ha'i: Eroticism and Exoticism in Representations of the Pacific. In Sites of Desire, Economies of Pleasure, Sexuali- 
ties in Asia and the Pacific, edited by Lenore Manderson and Margaret Jolly, 99-I 22; notes, 303-306. Chicago: University of Chicago Press.

200ra Infertile States, Person and Collectivity, Region and Nation in the Rhetoric of Pacific Population. In Borders of Being: State, Fertility and Sexuality in Asia and the Pacific, edited by Margaret Jolly and Kalpana Ram, 262-306. Ann Arbor: University of Michigan Press.

200 Ib On the Edge? Deserts, Oceans, Islands. In Native Pacific Cultural Studies on the Edge, edited by Vicente M Diaz and J Kèhaulani Kauanui. Special issue of The Contemporary Pacific I 3:4 I 7-466.

200Ic Imagining Oceania: Indigenous and Foreign Representations of a Sea of Islands. In Framing the Pacific in the 2 Ist Century: Coexistence and Friction, edited by Daizaburo Yui and Yasuo Endo, 29-48. Tokyo: Center for Pacific and American Studies, University of Tokyo.

2005 Serene and Unsettling Journeys: Reflections on the Oceanic in Robin White's Time to Go. In Les cultures à l'œuvre: Rencontres en art, edited by Michèle Coquet, Brigitte Derlon, and Monique Jeudy-Ballini, 273293. Paris: Maison des sciences de l'homme/Biro éditeur.

forthcoming Unsettling Memories: Commemorating "Discoverers" in Australia and Vanuatu in 2006. In Quiros et le Vanuatu, edited by Frédéric Angleviel. Port Vila: Sun Publications.

nd a The Sediment of Voyages: Re-membering Quirós, Bougainville and Cook in Vanuatu. In Oceanic Encounters, edited by Margaret Jolly, Serge Tcherkézoff, and Darrell Tryon. Manuscript under consideration by University of Hawai'i Press.

nd b Beyond the Beach: Re-Articulating the Limen in Oceanic Pasts, Presents and Futures. In Changing Contexts, Shifting Meanings: Transformations of Cultural Traditions in Oceania, edited by Elfriede Hermann. Manuscript under consideration by University of Hawai'i Press and Honolulu Academy of Arts.

Jolly, Margaret, and Mark Mosko, editors

I994 Transformations of Hierarchy: Structure, History and Horizon in the Austronesian World. Special issue of History and Anthropology 7 ( I4): I-I 8 .

Kabutaulaka, Tarcisius Tara

2005 Australian Foreign Policy and the RAMsi Intervention in Solomon Islands. The Contemporary Pacific I7:283-308.

Kame'eleihiwa, Lilikalā

I992 Native Land and Foreign Desires: Pehea Là E Pono Ai? How Shall We Live in Harmony? Honolulu: Bishop Museum Press.

Kasarherou, Emmanuel, and Cecile Mozziconacci

I998 Tjibaou Cultural Center. Nouméa: Agency for the Development of Kanak Culture. 
Kauanui, J Kēhaulani

2005 Precarious Positions: Native Hawaiians and US Federal Recognition. The Contemporary Pacific I7:I-27.

Linnekin, Jocelyn, and Lin Poyer, editors

I990 Cultural Identity and Ethnicity in the Pacific. Honolulu: University of Hawai'i Press.

May, Ron, editor

2003 "Arc of Instability"? Melanesia in the Early 200os. Occasional Paper No 4. Canberra: State, Society and Governance in Melanesia Project; Christchurch, NZ: Macmillan Brown Centre for Pacific Studies.

Moore, Clive

2004 Happy Isles in Crisis: The Historical Causes for a Failing State in the Solomon Islands, I998-2004. Canberra: Asia Pacific Press.

Narokobi, Bernard

I980 The Melanesian Way: Total Cosmic Vision of Life. Port Moresby: Institute of Papua New Guinea Studies.

National Museum of Australia

2006 Cook's Pacific Encounters: The Cook-Forster Collection of the GeorgAugust University of Göttingen. Exhibit catalog. Canberra: National Museum of Australia Press.

O’Brien, Patty

2006 The Pacific Muse: Exotic Femininity and the Colonial Pacific. Seattle: University of Washington Press

Otto, Ton

I997 After the "Tidal Wave": Bernard Narokobi and the Creation of a Melanesian Way. In Narratives of Nation in the South Pacific, edited by Nicholas Thomas and Ton Otto, 33-64. Chur, Switzerland: Harwood Academic Publishers.

Pangerl, Markus

nd Notions of "Insecurity" among Contemporary Indo-Fijian Communities. Manuscript. Copy in author's files.

Rawlings, Gregory E

I999 Villages, Islands and Tax Havens: The Global/Local Implications of a Financial Entrepôt in Vanuatu. Canberra Anthropology (The Asia Pacific Journal of Anthropology) 22 (2): 37-50.

2002 "Once there was a garden, now there is a swimming pool": Inequality, Labour and Land in Pango, a Peri-urban Village in Vanuatu. PhD thesis, Anthropology, The Australian National University.

Sahlins, Marshall

I963 Poor Man, Rich Man, Big-man, Chief: Political Types in Melanesia and Polynesia. Comparative Studies in Society and History 5:285-303. 
I985 Islands of History. Chicago: University of Chicago Press.

Salmond, Anne

1997 Two Worlds: Early Exchanges Between Maori and Europeans, I773I 8I 5. Auckland: Penguin Press.

2003 The Trial of the Cannibal Dog: Captain Cook in the South Seas. London: Allen Lane/Penguin Books.

Smith, Bernard

I985 European Vision and the South Pacific. Second edition. New Haven, Ст: Yale University Press. First published in I960.

Spriggs, Matthew

I997 The Island Melanesians. Oxford: Blackwell.

Taylor, John Patrick

forthcoming The Other Side: Ways of Being and Place in Vanuatu. Pacific Islands Monograph Series 22. Honolulu: University of Hawai'i Center for Pacific Islands Studies and University of Hawai'i Press.

Tcherkézoff, Serge

2003 A Long and Unfortunate Voyage toward the Invention of the Melanesia/Polynesia Opposition (I 595-I832). In Dumont d'Urville's Oceanic Provinces, Fundamental Precepts or Arbitrary Constructs, edited by Geoffrey Clark. Special issue of Journal of Pacific History 38 (2): I75-I96.

2004a "First Contacts" in Polynesia, The Samoan Case (I722-I 848): Western Misunderstandings about Sexuality and Divinity. Canberra: Journal of Pacific History Monographs; Christchurch, NZ: Macmillan Brown Centre for Pacific Studies.

2004b Tahiti 1768-Jeunes filles en pleurs: La face cachée des premiers contacts et la naissance du mythe occidental. Papeete: Au Vent des Îles.

Teaiwa, Katerina

2002 Visualising Te Kainga, Dancing Te Kainga: History and Culture between Rabi, Banaba and Beyond. PhD thesis, Anthropology, The Australian National University.

Teaiwa, Teresia, and Sean Mallon

2006 Ambivalent Kinships? Pacific People in New Zealand. In New Zealand Identities: Departures and Destinations, edited by James H Liu, Tim McCreanor, Tracey McIntosh, and Teresia Teaiwa, 207-229. Wellington, NZ: Victoria University Press.

Thomas, Nicholas

I989 The Force of Ethnology: Origins and Significance of the Melanesia/ Polynesia Division. Current Anthropology 30 (I): 27-34.

I996 Johann Reinhold Forster and His Observations and "On the Varieties of the Human Species," Forster's Comparative Ethnology. Introduction to Forster I996, xv-xxii, xxiii-xl. 
I997a Melanesians and Polynesians: Ethnic Typifications Inside and Outside Anthropology. In In Oceania: Visions, Artifacts, Histories, I33-I 55. Durham, NC: Duke University Press.

I997b Liberty and License: New Zealand Societies in Cook Voyage Anthropology. In In Oceania: Visions, Artifacts, Histories, 7I-92. Durham, NC: Duke University Press.

I997c Introduction: Tupaia's Map. In In Oceania: Visions, Artifacts, Histories, I-20. Durham, NC: Duke University Press.

Thompson, Roger C

1990 Australian Imperialism in the Pacific: The Expansionist Era, I820-I920. Melbourne, vic: Melbourne University Press.

Tryon, Darrell

nd Linguistic Encounters. In Oceanic Encounters, edited by Margaret Jolly, Serge Tcherkézoff, and Darrell Tryon. Manuscript under consideration by University of Hawai'i Press.

Turnbull, David

I998 Cook and Tupaia: A Tale of Cartographic Méconnaisance. In Science and Exploration in the Pacific: European Voyages in the Southern Oceans in the Eighteenth Century, edited by Margarette Lincoln, II7-I3I. Woodridge, Suffolk, UK and Rochester, NY: Boydell Press in association with the National Maritime Museum.

Underhill-Sem, Yvonne

I994 Blame It All on Population, Perceptions, Statistics and Reality in the Population Debate in the Pacific. In Sustainable Development or Malignant Growth? Perspectives of Pacific Island Women, edited by 'Atu Emberson-Bain, I-I 5. Suva: Marama Publications.

Wendt, Albert

I999 Afterword: Tatauing the Postcolonial Body. In Inside Out: Literature, Cultural Politics and Identity in the New Pacific, edited by Vilsoni Hereniko and Rob Wilson, 399-4I2. Lanham, MD: Rowman \& Littlefield.

Wilson, Rob, and Arif Dirlik, editors

I995 Asia/Pacific as Space of Cultural Production. Durham, NC: Duke University Press.

\section{Abstract}

This paper considers the relation of indigenous and foreign in how "the Pacific" and the "Pacific Rim" have been and are imagined. First, I ponder the power of cartography through the lens of two maps derived from the eighteenth century and speculate as to how such maps differed from indigenous genealogies of places 
and peoples. Second, I explore the origins and the lasting significance of the partitioning of the Pacific into the spatiotemporal regions of Polynesia, Melanesia, and Micronesia, and consider some indigenous uses of these foreign constructs. Third, I reflect on how academic and policy representations of the Pacific "region" and "rim" have been shaped by geopolitical concerns and developmentalism starting in the I970s, from the viewpoint of Australia (and in a more fleeting way, the United States). Fourth, through a brief exegesis of the influential writings of Epeli Hau'ofa, I consider his alternative vision of Oceania as a "sea of islands." Finally, I confront the specter of new ethnological typifications derived from a reading of "roots" and "routes" as dichotomy rather than dialectic, and stress the need for refocusing on the relations and creative exchanges between Islanders living in and between region and rim.

KEYwORds: Oceania, cartography, culture areas, Pacific region, Pacific Rim 